\title{
Nurse Media
}

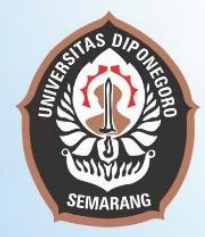

JOURNAL OF NURSING

Volume 9, Number 1 Year 2019, June 2019

Articles

- Quality of Work Life of Public School Nurses in the Philippines

- Effects of Spiritual Counseling on Spiritual Health-Quality of Life in Patients with HIVIAIDS

- Predicting Factors of Interpersonal and Situational Influences for Performing Stretching Exercises Based on Pender's Model

- The Effects of Mompyeogi Movement Exercise on Body Skin Temperature

- Filial Piety: From the Perspective of Indonesian Young Adults

- Effects of Family Empowerment on Increasing Family Support in Patients with Type-2 Diabetes Mellitus

- Effects of Islamic Spiritual Mindfulness on Stress among Nursing Students

- A Scoping Review of the Health Technology Procurement Decision Process in Indonesia

- Revisiting the Barriers to and Facilitators of Research Utilization in Nursing: A Systematic Review

- Purpose, Quality, and Value in Critical Realist Research within Nurse Education

Accredited by the Ministry of Research, Technology and Higher Education, Republic of Indonesia, No. 60/E/KPT/2016

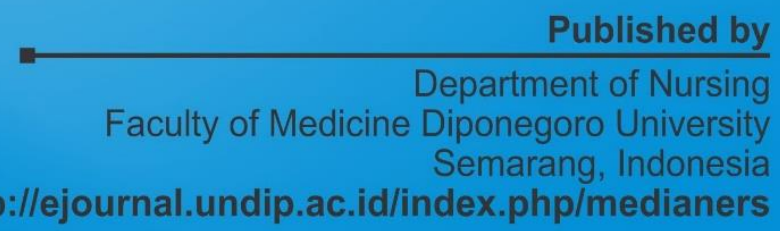

NURSE MEDIA

JOURNAL OF NURSING

\begin{tabular}{c|c} 
VOLUME & NUMBER \\
9 & 1
\end{tabular}

YEAR
2019

PAGES

ISSN

1 - 116 2087-7811 
e-ISSN: 2406-8799

p-ISSN: 2087-7811

\section{Nurse Media \\ Journal of Nursing}

\section{Volume 9 Number 1 Year 2019}

\section{Accredited by}

Indonesian Ministry of Research, Technology and Higher Education (Decree No: 60/E/KPT/2016)

\section{Editorial Office}

Department of Nursing

Faculty of Medicine, Diponegoro University

Jl. Prof. Soedarto, SH., Tembalang, Semarang 50275

Email: media_ners@live.undip.ac.id

Website: http://ejournal.undip.ac.id/index.php/medianers 


\section{EDITORIAL TEAM}

\section{Editor-in-Chief}

Sri Padma Sari

Department of Nursing, Faculty of Medicine, Diponegoro University, Indonesia

\section{Editorial Board}

- Yati Afiyanti

Faculty of Nursing, University of Indonesia, Indonesia

- Sri Warsini

School of Nursing, Universitas Gadjah Mada, Indonesia

- Jennieffer A Barr

School of Nursing and Midwifery, Central Queensland University, Australia

- Maarten M Kaaijk

School of Nursing, Hanze University of Applied Sciences, Netherlands

- Ferry Efendi

Faculty of Nursing, Universitas Airlangga, Indonesia

- Mardiyono Mardiyono

Department of Nursing, Health Polytechnics of Semarang, Indonesia

- Faustino Jerome Gulle Babate

Beta Nu Delta Nursing Society, Philippines

- Tantut Susanto

School of Nursing, University of Jember, Indonesia

- Cyruz P. Tuppal

St. Paul University Philippines System, Philippines

- Fatikhu Yatuni Asmara

Department of Nursing, Faculty of Medicine, Diponegoro University, Indonesia

\section{Associate Editors}

- Nana Rochana

Department of Nursing, Faculty of Medicine, Diponegoro University, Indonesia

- Asih Nurakhir

Department of Nursing, Faculty of Medicine, Diponegoro University, Indonesia

- Megah Andriany

Department of Nursing, Faculty of Medicine, Diponegoro University, Indonesia

\section{Layout Editor}

Pradipta Ary Pamungkas, Department of Nursing, Faculty of Medicine, Diponegoro

University, Indonesia

\section{Administration}

Septi Harni Wahyuningtyas, Department of Nursing, Faculty of Medicine, Diponegoro University, Indonesia 


\section{AIMS AND SCOPE}

The Nurse Media Journal of Nursing (NMJN) is an international nursing journal which publishes scientific works for nurses, academics and practitioners. NMJN welcomes and invites original and relevant research articles in nursing as well as literature reviews and case reports particularly in nursing.

This journal encompasses original research articles, review articles, and case studies, including:

- Adult nursing

- Emergency nursing

- Gerontological nursing

- Community nursing

- Mental health nursing

- Pediatric nursing

- Maternity nursing

- Nursing leadership and management

- Complementary and Alternative Medicine (CAM) in nursing

- Education in nursing

\section{PUBLICATION INFORMATION}

The Nurse Media Journal of Nursing (NMJN) is published twice a year, every June and December.

For year 2019, 2 issues (Volume 9, Number 1 (June) and Number 2 (December) are scheduled for publication.

The NMJN is published by the Department of Nursing, Faculty of Medicine, Diponegoro University and available at http://ejournal.undip.ac.id/index.php/medianers. It has been The journal has been indexed in the Google Scholar, Portal Garuda/Indonesian Publication Index (IPI), Indonesian Scientific Journal Database (ISJD), Directory of Open Access Journal (DOAJ), Science and Technology Index (Sinta), ASEAN Citation Index (ACI) and EBSCO.

\section{JOURNAL CITATION}

Articles of the Nurse Media Journal of Nursing have so far been cited

in: Google Scholar h-index / i10-index : : 12/14

Total articles published in Google Scholar : 77 (since 2012)

Total citations in Google Scholar : 403 (since 2012)

Total articles indexed in IPI : 99 (since 2014)

Total articles indexed in DOAJ : 77 (since 2015)

SINTA h-index / i10-index : 12/11 (since 2017)

Total Citations in SINTA : 400 (since 2017) 


\section{INDEXING AND ABSTRACTING}

The Nurse Media Journal of Nursing has been covered (indexed and abstracted) by the following indexing services:

- Google Scholar; (https://scholar.google.co.id/citations? user=Gs6nEgkAAAAJ\&hl=en)

- Portal Garuda/Indonesian Publication Index (IPI);

(http://id.portalgaruda.org/?ref=browse \&mod=viewjournal\&journal=1284)

- Indonesian Scientific Journal Database (ISJD) (http://isjd.pdii.lipi.go.id/index.php/Direktori-Jurnal.html)

- Directory of Open Access Journal (DOAJ). (https://doaj.org/toc/2406-8799?)

- Science and Technology Index (SINTA Score=S2) (http://sinta2.ristekdikti.go.id/journals/detail?id=914)

- ASEAN Citation Index (https://www.asean-cites.org/index.php? $r=$ contents\%2Findex\&id=9)

- EBSCO (https://atoz.ebsco.com)

- Garba Rujukan Digital (GARUDA) (http://garuda.ristekdikti.go.id/journal/view/1284)

- SHERPA/ROMEO (http://sherpa.ac.uk/romeo/search.php?issn=2087-7811)

- WORLDCAT (https://www.worldcat.org/search? $q=$ so $\% 3 A \% 22 N U R S E+M E D I A \% 22 \& q t=$ resul ts_page)

- Microsoft Academic (https://academic.microsoft.com/journal/2764736586)

- Crossref (https://search.crossref.org/?q=2406-8799)

- BASE (https://www.base-search.net) 


\section{TABLE OF CONTENTS}

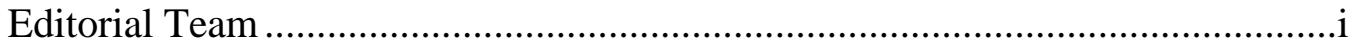

Aims and Scope, Publication Information, Journal Citation ..............................ii

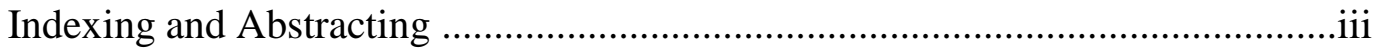

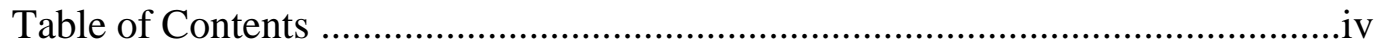

Preface, NMJN Vol. 9 No. 1 Year 2019 ...............................................................v-vi

Quality of Work Life of Public School Nurses in the Philippines

(Kaila Mae L. Macairan, Ryan Michael F. Oducado, Mika E. Minsalan,

Risa G. Recodo, Gio Franco D. Abellar) ...........................................................1-12

Effects of Spiritual Counseling on Spiritual Health-Quality of Life in Patients with HIV/AIDS

(Ulung Hasanah, Kusman Ibrahim, Aat Sriati)

Predicting Factors of Interpersonal and Situational Influences for Performing

Stretching Exercises Based on Pender's Model

(Mohammad Hossein Delshad, Sedigheh Sadat Tavafian, Anoshirvan

Kazemnejad)

The Effects of Mompyeogi Movement Exercise on Body Skin Temperature

(Swanny T Widyaatmadja, Kim Young-Duk)

Filial Piety: From the Perspective of Indonesian Young Adults

(Rahmi Setiyani, Carol Windsor)

Effects of Family Empowerment on Increasing Family Support in Patients

with Type-2 Diabetes Mellitus

(Iskim Luthfa, Iwan Ardian)....

Effects of Islamic Spiritual Mindfulness on Stress among Nursing Students

(Badrul Munif, Sri Poeranto, Yulian Wiji Utami).

A Scoping Review of the Health Technology Procurement Decision Process

in Indonesia

(Andrew Cashin, Roxsana Devi Tumanggor)

Revisiting the Barriers to and Facilitators of Research Utilization

in Nursing: A Systematic Review

(Cyruz P. Tuppal, Paolo D. Vega, Marina Magnolia G. Ninobla, Mark

Donald Reñosa, Abdullah Al-Battashi, Glenda Arquiza, Elizabeth P. Baua) ......90-102

Purpose, Quality, and Value in Critical Realist Research within Nurse

Education

(Phil Coleman)

$103-116$

Author Guidelines

App. $1-4$

Copyright Transfer Agreement.

App.5

Copyright Transfer Agreement Form

App. 6

Publication Ethics and Malpractice Statement

Submission Information

Acknowledgment

Author Indexing

Keyword Indexing

App. 14 


\section{PREFACE}

The Nurse Media Journal of Nursing (E-ISSN: 2406-8799, P-ISSN: 2087-7811) is an open access international journal which publishes the scientific works for nurse practitioners and researchers. The journal is published by the Department of Nursing, Faculty of Medicine, Diponegoro University, and strives to provide the most current and best research in the field of nursing. The journal has been indexed in the Google Scholar, Portal Garuda/Indonesian Publication Index (IPI), Indonesian Scientific Journal Database (ISJD), Directory of Open Access Journal (DOAJ), Science and Technology Index (Sinta), ASEAN Citation Index (ACI) and EBSCO. NMJN has applied for indexation in Scopus and is currently under revision.

It is also with pleasure to inform you that the Nurse Media Journal of Nursing (NMJN), has received accreditation from the Directorate General of Research Strengthening and Development, the Indonesian Ministry of Research, Technology and Higher Education. This accreditation is based on the decree number $60 / \mathrm{E} / \mathrm{KPT} / 2016$ dated on 13 November 2016 and will be valid until November 2021. Upon this achievement, the NMJN would like to thank all people (the NMJN editorial team, reviewers, authors) who have given their support and contribution in achieving this accreditation.

This issue (NJMN, Vol 9(1), 2019) has published ten articles, consisting of seven original research articles, and three reviews. This issue was authored and co-authored by the researchers and professionals from diverse countries, including Indonesia, Philippines, Iran, Republic of Korea, Australia, USA, Oman, and the United Kingdom. All papers have been doubled-blindly reviewed by the editors and reviewers of this journal.

The first article (Macairan, Oducado, Minsalan, Recodo, \& Abellar, 2019) is a correlational study which examined the quality of work life (QWL) among 57 public school nurses in the Philippines. The result of this study revealed that public school nurses had high QWL; the lowest mean scores were opportunities at work and social integration at work. The QWL was correlated with age, whereas sex, marital status, educational attainment, and length of work experience were not associated with QWL. The study recommends that public school nurses are provided with more chances for continuous professional growth and opportunities for better social integration to improve QWL.

The second article is a quasi-experimental study investigating the effects of spiritual counseling on the quality of life-spiritual health in patients with HIV/AIDS (Hasanah, Ibrahim, \& Sriati, 2019). Thirty patients were evenly assigned to the experimental group who received three sessions of spiritual counseling intervention and the control group. Results showed that there were significant differences in the spiritual health-quality of life between the control and experimental groups. Therefore, spiritual counseling could be a strategy in providing nursing care to improve the spiritual health-quality of life in HIV/AIDS patients.

The next article is authored by Delshad, Tavafian, and Kazemnejad (2019). It was a correlational study which predicted factors of interpersonal and situational influences for stretching exercise (SE) among office employees. Data were obtained from 420 office employees recruited by multi-stage cluster sampling in a university in Iran through the questionnaires of SE and interpersonal and situational influences based on Pender's Health Promotion Model. 
This study revealed that interpersonal influences and undergoing treatment had a significant relationship with stretching exercise, whereas there was no relationship between situational influences and stretching exercise. Through regression analysis, it was found that a strong predictor for stretching exercise behavior was interpersonal factors. Therefore, these factors could be integrated as an educational principle in facilitating admission behavior of stretching exercise.

The next article is an experimental study examining the effect of stretching exercise to body skin temperature (Widyaatmadja \& Young-Duk, 2019). This study involved 20 participants who received organ stretching of Mompyeogi movement exercise and were divided into two groups: males and females. The results revealed that participants who were at low temperature $(\mathrm{t}<330 \mathrm{C})$, underweight and had normal body mass index showed an increase in body skin temperature after performing the exercise. Meanwhile, participants aged 60 to 74 years old and performed normal chest respiration showed a stable temperature. The study recommends the practice of Mompyeogi movement exercise with deep abdominal inhalation for the variations of body skin temperature.

The fifth article (Setiyani \& Windsor, 2019) is a qualitative study exploring the meaning of filial responsibility among young adults within the social context of Indonesia. Eight university students participated in this study through in-depth interviews. The data were analyzed using a constructivist grounded theory method. The grand theme in this study was redefining the meaning of filial responsibility with four sub-themes: I am the one', 'not institutional care', 'the gendering of caregiving', and 'it is okay to do so'. This study provides an insight into the shifting patterns in elderly caregiving and support in Indonesia.

The sixth article is a quasi-experiment with non-equivalent control group design (Luthfa \& Ardian, 2019), which investigated the effects of family empowerment on increasing family support in patients with type 2 DM. Forty-six respondents were recruited using a consecutive sampling technique and assigned to the control and intervention groups. The intervention group received family empowerment programs for four times. The results showed that there was a significant difference in the family support between the intervention and the control group. Hence, it is recommended that health workers advocate and encourage the family in the planning management of patients with diabetes mellitus.

Another quasi-experimental study was also conducted by Munif, Poeranto, and Utami (2019). This study aimed to examine the effects of Islamic spiritual mindfulness therapy on decreasing stress among 36 nursing students working on the thesis. The participants were divided into the experimental group who received Islamic spiritual mindfulness and the control group. The results showed that there were significant differences in stress levels between the intervention group and the control group. The study suggests the practice of Islamic spiritual mindfulness as an alternative therapy to reduce stress.

The next article is authored by Cashin and Tumanggor (2019). This study is a scoping review which examines what is known of procurement decisions of advanced technology in healthcare generally and particularly in Indonesia. This study showed that there is a paucity of peer-reviewed literature to inform procurement decisions of health technology and incorporation into nursing practice. This study proposed two principals to move to a sustainable adoption and integration of advancing and emerging technology into practice- 
in the health care sciences as well as provide a scaffold to facilitate navigating what can be tricky waters constituted by enthusiasm and trepidation.

The ninth article is a systematic review (Tuppal et al., 2019). This review aims to critically identify, select, appraise, and synthesize research evidence about the barriers to and facilitators of research utilization. Thirty-six articles were included in the analysis of this study. It was revealed that the lack of awareness about research, lack of authority to change the practice, overwhelming publications, and lack of compiled literatures were the topmost identified barriers to research utilization. A consistent reproach on the capability of nurses to maximize and utilize research is suggested.

The last article is authored by Coleman (2018). This study is a Critical Realist review to explore the purpose of educational research, how quality can be assured in such research, and how the value of a research study in nurse education can be determined. The result showed that a wide range of criteria were identified to evaluate the purpose, quality, and value of Critical Realist research. Hence, nurse education should explicitly reflect several principles such as the holistic, theoretically-eclectic, pragmatic, and solution-focused nature of nursing.

Finally, the NJMN would like to thank the respective authors, reviewers, and editors for their contribution and collaboration in publishing this current issue. Furthermore, the editors would like to appreciate and call for academic papers from the nurse-practitioners, academicians, professionals, graduates and undergraduate students, fellows, and associates pursuing research throughout the world to contribute to this international journal.

Semarang, June 2019

Sri Padma Sari

Editor-in-Chief

The Nurse Media Journal of Nursing 